\title{
PENGARUH MODEL PEMBELAJARAN PROBLEM BASED FLIPPED CLASSROOM TERHADAP KETERAMPILAN PEMECAHAN MASALAH SISWA KELAS XI IPA
}

\author{
I.W. Arnata ${ }^{1}$, I. B. P. Mardana ${ }^{2}$, I. N. P. Suwindra ${ }^{3}$ \\ ${ }^{1,2,3}$ Program Studi Pendidikan Fisika, Universitas Pendidikan Ganesha \\ e-mail:wayan.arnata@undiksha.ac.id,putu.mardana@undiksha.ac.id, suwindra@undiksha.ac.id
}

\begin{abstract}
Abstrak
Tujuan penelitian ini adalah menganalisis perbedaan keterampilan pemecahan masalah siswa antara siswa yang belajar dengan model Problem Based Flipped Classroom (PBFC), model Traditional Flipped Classroom (TFC), dan model Direct Instruction (DI). Penelitian ini merupakan penelitian quasi eksperimen dengan desain post-test only control group design. Populasi penelitian ini berjumlah 357 siswa kelas XI IPA SMA Negeri 8 Denpasar dengan sampel penelitian berjumlah 107 siswa dan terdistribusi ke dalam tiga kelas. Data keterampilan pemecahan masalah siswa diperoleh melalui tes keterampilan pemecahan masalah dan dianalisis menggunakan analisis deskripsif dengan taraf signifikansi $5 \%$. Hasil penelitian ini menunjukan adanya perbedaan keterampilan pemecahan masalah siswa antara kelompok yang belajar dengan model PBFC, model TFC, dan model DI. Hal ini dibuktikan dengan hasil uji hipotesis menggunakan ANAKOVA yang menunjukan nilai statistik $F^{*}=1317.899$ dengan angka signifikansi 0,001 $(p<0,05)$ yang berarti hipotesis penelitian diterima. Hasil uji LSD menunjukan bahwa keterampilan pemecahan masalah siswa yang belajar dengan model PBFC lebih tinggi dibandingkan dengan TFC dan DI
\end{abstract}

Kata Kunci: Model PBFC, Model TFC, Model DI, Keterampilan Pemecahan Masalah

\begin{abstract}
This research aimed at analyzing the differences in students' problem solving abilities between the students who learned by using problem based flipped classroom (PBFC) model, traditional flipped classroom (TFC) model and direct instruction (DI) model. This research was a quasi-experimental study with a post-test only control group design. The population of this study was 357 students of class XI IPA of SMA Negeri 8 Denpasar with 107 students as the sample and was distributed into three classes. The data of students' problem solving abilities were obtained through the problem solving ability tests and were analyzed descriptively with a significance level of $5 \%$. The result of this study indicates that there are differences in students' problem solving abilities between the group of students who learn by using the PBFC model, the TFC model, and the DI model. This is proved by the results of hypothesis testing using ANACOVA which shows a statistical value $F^{*}$ is 1317,899 with a significance value of $0.001 \quad(p<0.05)$ which means that the research hypothesis is accepted. LSD test results show that the problem-solving abilities of students who learn by using PBFC models are higher than those who learn by using TFC and DI.
\end{abstract}

Keywords: PBFC model, TFC model, DI model, problem solving skills

\section{PENDAHULUAN}

Tantangan kehidupan untuk bersaing disegala aspek pada abad ke-21 semakin besar. Teknologi dan pasar bebas berkembang sangat pesat menuntut tersedianya sumber daya manusia berkualitas, berintegritas dan memiliki skill. Keterampilan abad 21 harus dimiliki seseorang untuk mencapai hal tersebut. Keterampilan tersebut dapat diperoleh seseorang melalui pendidikan, sehingga pendidikan menjadi peran penting dalam menciptakan sumber daya manusia yang berkualitas. Selaras dengan hal tersebut, indikator penting dalam 
Jurnal Pendidikan Fisika Undiksha, Vol. 10 No.1, Juli 2020

p-ISSN : 2599-2554 (Print), e-ISSN : 2599-2562 (online)

mendukung program Sustainable Development Goals (SDGs) yaitu Quality of Education atau kualitas pendidikan.

Partnership for $21^{\text {st }}$ Century Skills (2015) menyatakan bahwa keterampilan pada abad ke-21 mencakup (1) berpikir kritis dan keterampilan pemecahan masalah, (2) berkomunikasi dan berkolaborasi, (3) kreatifitas dan inovasi. Partnership for $21^{\text {st }}$ Century Skills (2015) menyatakan bahwa keterampilan pada abad ke-21 mencakup (1) berpikir kritis dan keterampilan pemecahan masalah, (2) berkomunikasi dan berkolaborasi, (3) kreatifitas dan inovasi. Kompetensi yang dituntut saat ini ialah merumuskan masalah, menentukan variabel, mengajukan hipotesis, mengolah dan menganalisis data, memilih instrumen, menarik kesimpulan, mengomunikasikan serta menganalisis dan menyelesaikan masalah yang tertuang di dalam Peraturan Menteri dan Kebudayaan Nomor 21 Tahun 2016 mengenai standar isi pendidikan dasar dan menengah, pada kompetensi isi bagian humaniora. Sejalan dengan hal itu, Susanto (2019) berpendapat bahwa keterampilan pemecahan masalah adalah keterampilan yang harus dimiliki setiap orang untuk menemukan sebuah solusi dari suatu permasalahan. Proses pemecahan masalah melibatkan pemerolehan dan pengorgarnisasian informasi, dan melibatkan pencarian yang layak untuk mencapai tujuan. Kemampua pemecahan masalah merupakan strategi kognitif yang diperlukan seseorang dalam kehidupan sehari-hari termasuk para siswa dalam kegiatan pembelajaran (Susanto, 2019).

Pendidikan adalah usaha sadar dan terencana untuk mewujudkan suasana belajar dan proses belajar agar siswa secara aktif memiliki kekuatan spiritual keagamaan, pengendalian diri, kepribadian, kecerdasan, akhlak mulia, dan keterampilan yang diperlukan dirinya, masyarakat, bangsa, dan negara yang ditegaskan oleh Undang-Undang Republik Indonesia Tahun 2003 tentang Sistem Pendidikan Nasional. Fisika merupakan salah satu ilmu yang menopang berkembangnya kemajuan teknologi dan pendidikan abad ke-21. Tujuan pembelajaran fisika yang tertuang dalam kerangka kurikulum 2013 adalah mempunyai keterampilan mengembangkan pengetahuan dan sikap percaya diri sebagai bekal untuk melanjutkan pendidikan pada jenjang yang lebih tinggi serta mengembangkan ilmu pengetahuan dan teknologi (Kemendikbud, 2014).Keberhasilan pendidikan tidak hanya diukur dari hasil yang diperoleh siswa berupa nilai, namun juga proses yang dilakukan siswa dalam pembelajaran. Seyogyanya, harapan tersebut dicapai guna meningkatkan hasil dan kualitas proses pembelajaran fisika.

Realita di lapangan menunjukan hasil pembelajaran fisika di Indonesia masih rendah. Hal ini ditunjukan oleh survei dari Programme for International Student Assesment tahun 2015. Skor rata-rata pada pelajaran sains yang diterima Indonesia adalah 403 dan menduduki peringkat 69 dari 76 negara. Selaras dengan hasil survei tersebut, hasil penelitian Trends in Mathematics and Science Study (TMSS) tahun 2015 menunjukan bahwa dalam bidang sains, Indonesia menduduki peringkat ke-45 dari 48 negara peserta dengan perolehan poin 397 poin (Rahmawati, 2015). Hal ini terjadi karena faktor keterampilan pemecahan masalah siswa yang masih rendah. Penyebab kurangnya keterampilan pemecahan masalah yang dimiliki siswa adalah kurangnya kreativitas dan penalaran siswa dalam memecahkan masalah konteks yang nyata (Suarsana et al., 2019). Selain itu, siswa tidak dapat melaksanakan proses pemecahan masalah sesuai dengan empat langkah berikut, yaitu (1) memahami masalah, (2) menyusun rencana, (3) melaksanakan rencana, (4) mengevaluasi (Suarsana et al., 2019).

Rendahnya keterampilan pemecahan masalah ditunjukan oleh berbagai fakta empiris dari beberapa penelitian. Penelitian yang dilakukan oleh Chis et al. (2018) menunjukan rendahnya keterampilan pemrograman siswa diakibatkan oleh rendahnya keterampilan pemecahan masalah siswa. Hal seirama diungkapkan oleh Chang el al. (2018) bahwa pencapaian akademik siswa masih rendah. Penyebabnya adalah direct instruction yang 
Jurnal Pendidikan Fisika Undiksha, Vol. 10 No.1, Juli 2020

p-ISSN : 2599-2554 (Print), e-ISSN : 2599-2562 (online)

ditekankan secara berlebihan, menyebabkan siswa mudah frustasi dan tidak mendukung keterampilan pemecahan masalah. Proses pembelajaran yang kurang edutainment juga menjadi penyebab rendahnya keterampilan pemecahan masalah siswa (Chis et al., 2018). Suasana belajar yang menyenangkan dapat diperoleh apabila guru melibatkan pemanfaatan teknologi di dalamnya. Penelitian mengenai rendahnya keterampilan pemecahan masalah di Indonesia siswa dilakukan oleh Susanto (2019), ditunjukan dari skor pre-test rata-rata siswa kurang dari 35\%. Penelitian Utami (2017) menunjukan bahwa nilai rata-rata indikator memahami masalah yakni 49,26 karena siswa tidak menuliskan unsur-unsur yang diketahui pada soal, oleh karena itu sebagian besar siswa masih tidak memahami masalah yang diberikan.

Ketidak sesuaian antara harapan dan kenyataan disebabkan oleh pembelajaran fisika yang berpusat kepada guru, yaitu dengan model pembelajaran langsung (direct instruction). Direct instruction menyebabkan pembelajaran di kelas hanya satu arah, keterlibatan siswa dalam pembelajaran menjadi pasif dan kurang bermakna. Penelitian Abu Bakar dan Maria Elvin (2018) mengatakan bahwa faktor yang menyebabkan rendahnya keterampilan pemecahan masalah siswa adalah metode pembelajaran yang digunakan oleh guru saat mengajar tidak menarik dan ceramah.

Pemanfaatan kemajuan teknologi diharapkan dapat menciptakan suasana belajar edutainment (education and entertainment). Inovasi pembelajaran hendaknya mampu meningkatkan keterampilan pemecahan masalah siswa yaitu dengan menggunakan model pembelajaran yang berbasis teknologi dan mampu menerapkan pembelajaran yang berpusat kepada siswa. Sesuai dengan perkembangan zaman, maka dalam perkembangan pembelajaran telah banyak dikembangkan dengan mengoptimalkan penggunaan e-learning. Model pembelajaran flipped classroom adalah hasil dari gagasan baru dan termasuk model pembelajaran berbasis e-learning yang mendukung evolusi industri 4.0 dan pembelajaran abad ke-21. Flipped classroom dapat menjadi model pembelajaran yang memungkinkan peserta didik untuk mengolah sendiri lingkungan belajar dan meningkatkan motivasi mereka untuk memecahkan masalah (Qader \& Arslan, 2019). Menurut Brown (dalam Qader \& Arslan, 2019) kelas bukan satu-satunya untuk siswa belajar, namun sebaliknya siswa dapat belajar kapan saja dan dimana saja menggunakan teknologi informasi yang sangat maju.

Kombinasi antara PBL dan flipped classroom menciptakan suasana belajar edutainment dan pembelajaran otentik (Chis et al., 2018). Flipped Classroom didasarkan pada prinsip pembelajaran edutainment karena membuat lingkungan belajar yang aktif. Melalui video, pembelajaran dapat dilakukan kapanpun dan dimanapun tidak terbatas hanya pada ruang kelas. Sedangkan Problem Based Learning memfokuskan siswa untuk memecahkan masalah. Dengan demikian, kombinasi antara FC dan PBL memungkinkan siswa untuk menghabiskan waktu di luar kelas untuk belajar, dan di dalam untuk memecahkan permasalahan (Chis et al., 2018). Bukti empiris model problem based flipped classroom efektif untuk meningkatkan keterampilan pemecahan masalah siswa adalah hasil penelitian Utami (2017) melalui penerapan model pembelajaran problem based flipped classroom dapat meningkatkan keterampilan pemecahan masalah siswa. Senada dengan hal tersebut, Srilaphat (2019) menyatakan bahwa model problem based flipped classroom efektif digunakan untuk meningkatkan keterampilan pemecahan masalah siswa. Penelitian yang dilakukan Qader \& Arslan (2019) menunjukan terdapat peningkatan yang sangat signifikan dalam nilai tes rata-rata siswa yang telah menerima flipped classroom dibandingkan dengan hasil tes yang sangat rendah diperoleh oleh siswa yang menerima kelas tradisional. Penelitian yang dilakukan oleh Chis et al. (2018) menunjukan skor pre-test hanya $7,5 \%$ siswa yang mampu lulus dalam skor minimal, sedangkan pada post-test jumlah siswa yang mampu lulus skor minimal sebesar $71,7 \%$. Hal ini menunjukan terjadi peningkatan keterampilan pemrogaman siswa. Penelitian Syahril et al (2019) keterampilan pemecahan masalah mahasiswa di prodi pendidikan matematika IPTS sebelum menggunakan 
model pembelajaran flipped classroom mencapai nilai rata-rata 51,60. Tujuan penelitian ini adalah mendeskripsikan perbedaan keterampilan pemecahan masalah siswa antara yang belajar dengan PBFC, TFC, Model DI.

\section{METODE}

Penelitian ini menggunakan jenis penelitian eksperimen semu (quasi-experiment). Jenis penelititan ini memiliki kontrol, namun tidak berfungsi sepenuhnya untuk mengontrol variabelvariabel luar yang memengaruhi eksperimen. Desain penelitian yang digunakan adalah posttest only control group design. Desain ini melibatkan dua kelompok, yaitu kelompok kontrol dan kelompok eksperimen. Hubungan sebab-akibat ke dua kelompok tersebut ditunjukan pada Gambar 1

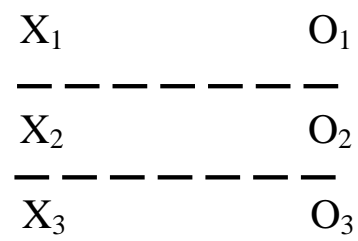

Gambar 1.

Desain penelitian

$\begin{array}{ll}\text { Keterangan } & : \\ \mathrm{X}_{1} & : \text { Perlakuan dengan model PBFC } \\ \mathrm{X}_{2} & : \text { Perlakuan dengan model TFC } \\ \mathrm{X}_{3} & : \text { Perlakuan dengan modelDI } \\ \mathrm{O}_{1}, \mathrm{O}_{2}, \mathrm{O}_{3} & \begin{array}{l}\text { Keterampilan pemecahan } \\ \text { masalah siswa }\end{array}\end{array}$

Populasi dalam penelitian ini adalah seluruh siswa kelas XI IPA SMA Negeri 8 Denpasar semester genap tahun ajaran 2019/2020 yang terdistribusi dalam 8 kelas, yaitu kelas XI IPA 1, kelas XI IPA 2, kelas XI IPA 3, kelas XI IPA 4, XI IPA 5, XI IPA 6, XI IPA 7, kelas XI IPA 8, XI IPA 9, dan XI IPA 10. Semua kelas dalam populasi tersebut telah terdistribusi homogen secara akademik. Sampel penelitian terdiri dari dua kelas, yaitu kelas kontrol dan kelas eksperimen. Pemilihan sampel dalam penelitian ini menggunakan random assignment atau teknik pembagian acak. Pemilihan sampel dalam penelitian tidak langsung dilakukan pengacakan individu dalam populasi, karena individu dalam populasi sudah terdistribusi ke dalam masing-masing kelas. Penelitian ini menggunakan sampel sebanyak 107 siswa atau 29,97\% (>15\%) dari jumlah populasi. Jumlah sampel sudah representatif mewakili jumlah populasi penelitian. Sampel yang terdiri dari tiga kelas mendapatkan perlakuan yang berbeda, pada kelas eksperimen pertama mendapat perlakuan model PBFC, kelas eksperimen ke dua dengan perlakuan model TFC, dan kelas kontrol mendapat perlakuan model DI.

Penelitian ini menggunakan prosedur dengan tahapan sebagai berikut Prosedur pada penelitian ini menggunakan tiga tahap yaitu (1) Tahap persiapan yang terdiri dari observasi awal ke tempat penelitian, merancang instrumen dan perangkat penelitian, melakukan uji coba instrument penelitian, dan melakukan revisi terhadap instrumen penelitian yang telah di uji coba. (2) Tahap pelaksanaan yang terdiri dari pemberian tes keterampilan pemecahan awal siswa, pelaksanaan kegiatan pembelajaran, dan pelaksanaan posttest. (3) Tahap tindak lanjut yang terdiri dari analisis data dan pembahasan. Instrumen penelitian ini adalah tes keterampilan pemecahan masalah siswa dengan 10 butir soal esay. Data yang diperoleh dari penelitian ini melalui tes keterampilan pemecahan masalah siswa awal dan posttest. 
Jurnal Pendidikan Fisika Undiksha, Vol. 10 No.1, Juli 2020

p-ISSN : 2599-2554 (Print), e-ISSN : 2599-2562 (online)

\section{HASIL DAN PEMBAHASAN}

Hasil keterampilan pemecahan masalah siswa yang belajar menggunakan model pembelajaran PBFC memiliki skor keterampilan pemecahan masalah awal pada kategori sanggat tinggi, tinggi, dan cukup sebanyak $0 \%$, sedangkan pada kategori rendah sebanyak $19,44 \%$, dan sangat rendah sebanyak $80,56 \%$. Siswa yang belajar dengan model pembelajaran TFC memiliki skor keterampilan pemecahan masalah awal pada kategori sanggat tinggi, tinggi, dan cukup sebanyak $0 \%$, sedangkan pada kategori rendah sebanyak $28,57 \%$, dan sangat rendah sebanyak $71,43 \%$. Siswa yang belajar dengan model pembelajaran DI memiliki keterampilan pemecahan masalah awal pada kategori sangat tinggi, tinggi, dan cukup sebanyak $0 \%$, sedangkan pada kategori rendah sebanyak $36,11 \%$, dan kategori sangat rendah sebanyak $63,89 \%$. Skor rata-rata (M) dan standar deviasi (SD) hasil keterampilan pemecahan masalah siswa sebelum perlakuan pada kelompok model pembelajaran PBFC, model pembelajaran TFC, dan model pembelajaran DI untuk setiap analisis dengan setiap unit berurutan yaitu $(\mathrm{n} 1=\mathrm{n} 3=36$, n2=35) disajikan pada Tabel 1

Tabel 1. Nilai rata-rata dan standar deviasi keterampilan pemecahan masalah siswa

\begin{tabular}{ccccc}
\hline Kelas & Model Pembelajaran & M & SD & Kualifikasi \\
XI IPA 1 & PBFC & 32,62 & 6,23 & Sangat Rendah \\
XI IPA 4 & TFC & 33,71 & 7,25 & Sangat Rendah \\
XI IPA 2 & DI & 34,91 & 7,09 & Sangat Rendah \\
\hline
\end{tabular}

Keterangan:

PBFC : Probem Based Flipped Classroom

TFC : Traditional Flipped Classroom

DI : Direct Instruction

Keterampilan pemecahan masalah siswa terdiri dari 4 dimensi yang dapat diukur pada setiap butir soal. Nilai rata-rata keterampilan pemecahan masalah siswa sebelum perlakuan untuk setiap dimensi pada kelompok PBFC, TFC, dan DI disajikan pada Tabel 2

Tabel 2. Nilai rata-rata kemapuan pemecahan masalah siswa tiap dimensi sebelum perlakuan

\begin{tabular}{lcccc}
\hline Kelompok & \multicolumn{4}{c}{ Rata-Rata Dimensi KPM } \\
& KPM 1 & KPM 2 & KPM 3 & KPM 4 \\
PBFC & 81,39 & 35,83 & 21,18 & 0,28 \\
TFC & 86,14 & 39,00 & 16,71 & 4,71 \\
DI & 91,25 & 41,39 & 17,01 & 1,38 \\
\hline
\end{tabular}

Keterangan:

KPM 1 : Memahami Masalah

KPM 2 : Menyusun Rencana

KPM 3: Melaksanakan Rencana

KPM 3 : Memeriksa Kembali

Setelah tes keterampilan pemecahan masalah siswa awal dilakukan, maka dilaksanakan proses pembelajaran. Proses pembelajaran dilakukan dengan 6 kali pertemuan. Tiga pertemuan awal penelitian ini pada sintaks in class siswa belajar tatap muka di kelas. Sedangkan tiga pertemuan akhir penelitian ini pada sintaks in class siswa belajar tatap muka di dalam jaringan. Pemberian post-test dilakukan setelah siswa memperoleh perlakuan, dengan hasil sebagai berikut: kelompok siswa yang belajar menggunakan model pembelajaran PBFC memiliki keterampilan pemecahan masalah dengan kategori sangat tinggi sebanyak 30,55\%, kategori tinggi 55,56\%, kategori cukup sebanyak 13,89\%, sedangkan kategori rendah dan 
sangat rendah sebanyak $0 \%$. Kelompok siswa yang belajar menggunakan model pembelajaran DI memiliki keterampilan pemecahan masalah dengan kategori sangat tinggi sebanyak $14,29 \%$, kategori tinggi sebanyak $60,00 \%$, kategori cukup sebanyak $25,71 \%$, sedangkan kategori rendah dan sangat rendah sebanyak $0 \%$. Kelompok siswa yang belajar menggunakan model pembelajaran TFC memiliki keterampilan pemecahan masalah dengan kategori sangat tinggi sebanyak $2,78 \%$, kategori tinggi sebanyak $38 \%$, kategori cukup sebanyak $58,33 \%$, sedangkan kategori rendah dan sangat rendah sebanyak $0 \%$. Nilai rata-rata (M) dan standar deviasi (SD) hasil keterampilan pemecahan masalah siswa setelah perlakuan (posttest) pada kelompok model pembelajaran PBFC, model pembelajaran TFC, dan model pembelajaran DI untuk setiap analisis dengan jumlah setiap unit berturut-turut yaitu $(n 1=n 3=36, n 2=35)$ disajikan pada Tabel 3.

Tabel 3. Nilai rata-rata dan standar deviasi keterampilan pemecahan masalah siswa setelah perlakuan

\begin{tabular}{ccccc}
\hline Kelas & Model Pembelajaran & M & SD & Kualifikasi \\
XI IPA 1 & PBFC & 79,38 & 7,76 & Tinggi \\
XI IPA 4 & TFC & 75,57 & 8,23 & Tinggi \\
XI IPA 2 & DI & 68,82 & 8,17 & Cukup \\
\hline
\end{tabular}

Nilai rata-rata keterampilan pemecahan masalah siswa setelah perlakuan untuk setiap dimensi pada kelompok PBFC, TFC, dan DI disajikan pada Tabel 4

Tabel 4. Nilai rata-rata setiap dimensi keterampilan pemecahan masalah siswa setelah perlakuan

\begin{tabular}{lcccc}
\hline \multicolumn{1}{c}{ Kelompok } & \multicolumn{4}{c}{ Rata-Rata Dimensi KPM } \\
PBFC & 99,72 & KPM 2 & KPM 3 & KPM 4 \\
TFC & 98,57 & 79,58 & 73,88 & 61,11 \\
DI & 100,00 & 79,64 & 70,00 & 56,65 \\
\hline
\end{tabular}

Dikaji secara deskriptif, peningkatan nilai rata-rata keterampilan pemecahan masalah siswa yang dicapai kelompok dengan model pembelajaran PBFC sebesar 46,76. Hasil tersebut lebih tinggi dibandingkan hasil yang dicapai oleh kelompok model pembelajaran TFC yaitu sebesar 41,85, maupun hasil yang dicapai kelompok model pembelajaran DI yaitu sebesar 33,91. Hasil tersebut menunjukan bahwa nilai rata-rata keterampilan pemecahan masalah siswa kelompok model pembelajaran PBFC relatif lebih tinggi dibandingkan dengan nilai rata-rata keterampilan pemecahan masalah oleh kelompok model pembelajaran TFC ataupun DI. Hal ini menunjukan terdapat perbedaan rata-rata keterampilan pemecahan masalah siswa antara kelompok siswa yang belajar dengan model pembelajaran PBFC, TFC, dan DI.

Teknik analisis data yang digunakan untuk menguji hipotesis adalah analisis kovarian (ANAKOVA). Sebelum pengujian hipotesis dilaksanakan, pengujian asumsi ANAKOVA yaitu uji normalitas, uji homogenitas, dan uji linieritas harus dilaksanakan dan terpenuhi. Pengujian pertama yaitu uji normalitas sebaran data dilakukan terhadap seluruh data keterampilan pemecahan masalah siswa, baik dari kelompok model pembelajaran PBFC, kelompok model pembelajaran TFC, dan kelompok model pembelajaran DI. Uji normalias sebaran data dilakukan dengan statistik Kolmogorov-Smirnov dan Shaoiro-Wilk. Analisis data yang dilakukan penggunakan bantuan software SPSS 24 for Windows. Ringkasan hasil uji normalitas data ditampilkan pada Tabel 5. 
Jurnal Pendidikan Fisika Undiksha, Vol. 10 No.1, Juli 2020

p-ISSN : 2599-2554 (Print), e-ISSN : 2599-2562 (online)

Tabel 5. Ringkasan hasil uji normalitas data (test of normality)

\begin{tabular}{cccccccc}
\hline \multicolumn{1}{c}{ Model } & & Kolmogorov-Smirnov ${ }^{\mathrm{a}}$ & \multicolumn{3}{c}{ Shapiro-Wilk } \\
keterampilan & PBFC & 0,138 & 36 & 0,091 & 0,944 & 36 & 0,076 \\
pemecahan & TFC & 0,111 & 35 & $0,200^{*}$ & 0,968 & 35 & 0,383 \\
masalah & DI & 0,120 & 36 & $0,200^{*}$ & 0,952 & 36 & 0,131 \\
awal siswa & & & & & & & \\
Skor & PBFC & 0,137 & 36 & 0,092 & 0,956 & 36 & 0,178 \\
Posttest & TFC & 0,142 & 35 & 0,072 & 0,952 & 35 & 0,130 \\
& DI & 0,146 & 36 & 0,058 & 0,950 & 36 & 0,116 \\
\hline
\end{tabular}

Berdasarkan Tabel 5 terlihat bahwa pada statistik Kolmogorov-Smirnov dan Shapiro-Wilk, skor keterampilan pemecahan masalah awal siswa dan posttest ke tiga kelompok model pembelajaran memiliki signifikansi lebih besar dari 5\% atau 0,05. Hal tersebut menandakan bahwa data keterampilan pemecahan masalah awal siswa dan posttest keterampilan pemecahan masalah siswa untuk ke tiga kelompok model pembelajaran berdistribusi normal.

Uji homogenitas varian antar kelompok dilakukan terhadap seluruh data kemapuan pemecahan masalah siswa. Uji homogenitas varian antar kelompok menggunakan levene's test of equality of error variance. Ringkasan hasil pengujian homogenitas varian ditampilkan pada Tabel 6.

Tabel 6. Ringkasan pengujian homogenitas varian antar kelompok

\begin{tabular}{|c|c|c|c|c|c|}
\hline & Source & $\begin{array}{l}\text { Levene } \\
\text { Statistic }\end{array}$ & df1 & $\mathrm{df2}$ & Sig. \\
\hline \multirow{4}{*}{$\begin{array}{c}\text { Keterampilan } \\
\text { pemecahan } \\
\text { masalah } \\
\text { awal siswa }\end{array}$} & Based on Mean & 0.710 & 2 & 104 & 0,494 \\
\hline & Based on Median & 0,635 & 2 & 104 & 0,532 \\
\hline & $\begin{array}{l}\text { Based on Median and with } \\
\text { adiusted df }\end{array}$ & 0,635 & 2 & 103.316 & 0,532 \\
\hline & Based on trimmed mean & 0,684 & 2 & 104 & 0,507 \\
\hline \multirow{4}{*}{$\begin{array}{c}\text { Skor } \\
\text { Posttest }\end{array}$} & Based on Mean & 0,185 & 2 & 104 & 0,831 \\
\hline & Based on Median & 0,156 & 2 & 104 & 0,856 \\
\hline & $\begin{array}{l}\text { Based on Median and with } \\
\text { adiusted df }\end{array}$ & 0,156 & 2 & 101.444 & 0,856 \\
\hline & Based on trimmed mean & 0,166 & 2 & 104 & 0,847 \\
\hline
\end{tabular}

Berdasarkan Tabel 6, hasil pengujian homogenitas varian terhadap data yang diperoleh menunjukan nilai-nilai statistik Levene memiliki angka-angka signifikansi yang lebih besar dari $5 \%$ atau 0,05. Dapat disimpulkan varian data antar kelompok belajar adalah homogen.

Pengujian linieritas dilakukan untuk menunjukan sebaran data yang linier. Data linier jika nilai signifikansi dari linearity lebih kecil dari 0,05 dan deviation from linearity lebih besar dari 0,05. Ringkasan hasil uji linieritas untuk kelompok model pembelajaran PBFC, TFC, dan DI ditunjukan pada Tabel 7.

Tabel 7. Ringkasan hasil uji linieritas

\begin{tabular}{|c|c|c|c|c|c|c|c|}
\hline & Source & & $\begin{array}{l}\text { Sum of } \\
\text { Squares }\end{array}$ & $d f$ & $\begin{array}{l}\text { Mean } \\
\text { Square }\end{array}$ & $F$ & Sig \\
\hline Pos & Between & & 7403,984 & 25 & 296,159 & 5,5 & 0,0 \\
\hline Kete & & Line & 55 & 1 & 5511.514 & 103,310 & \\
\hline $\begin{array}{l}\text { pemecahan } \\
\text { masalah }\end{array}$ & & $\begin{array}{l}\text { Deviation } \\
\text { from }\end{array}$ & $18 s$ & 24 & 78,853 & 1,478 & 0,1 \\
\hline
\end{tabular}




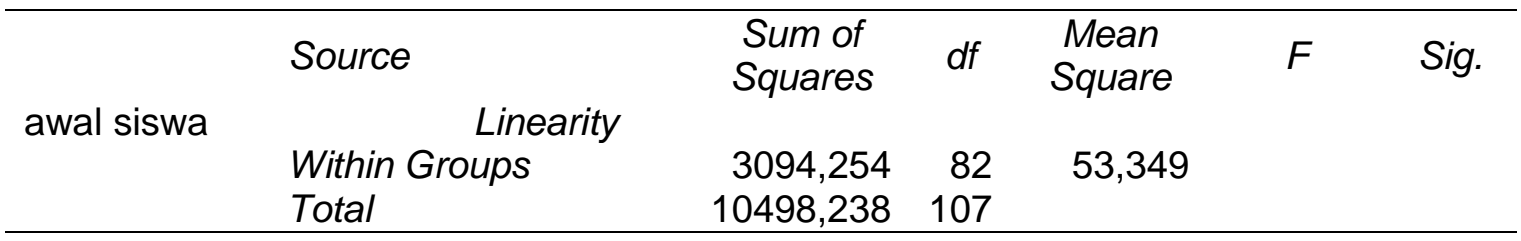

Berdasarkan Tabel 7, nilai F Deviation from Linearity dengan nilai signifikansi 0,114 menunjukan bahwa nilai signifikansinya lebih besar dari $5 \%$ atau 0,05 . Artinya keterampilan pemecahan masalah awal siswa dengan keterampilan pemecahan masalah siswa setelah perlakuan adalah linier. Nilai F linearity menunjukan 103,310 dengan signifikansi lebih kecil dari 5\% atau 0,05, artinya keterampilan pemecahan masalah siswa sebelum perlakuan secara signifikan linier terhadap keterampilan pemecahan masalah siswa.Pengujian hipotesis dalam penelitian ini dilakukan menggunakan analisis kovarian (ANAKOVA) satu jalur. Uji kovarian dilakukan dengan bantuan software SPSS 24 for windows. Ringkasan hasil ANAKOVA ditampilkan pada Tabel 8.

Tabel 8. Ringkasan hasil anakova untuk pengujian hipotesis

\begin{tabular}{lccccc}
\hline \multicolumn{1}{c}{ Source } & $\begin{array}{c}\text { Type III Sum } \\
\text { of Squares }\end{array}$ & Df & $\begin{array}{c}\text { Mean } \\
\text { Square }\end{array}$ & $\mathrm{F}^{*}$ & Sig. \\
$\begin{array}{l}\text { Corrected } \\
\text { Model }\end{array}$ & $8315,532^{\mathrm{a}}$ & 3 & 2771,844 & 583,660 & 0,000 \\
$\begin{array}{l}\text { Intercept } \\
\text { Keterampilan }\end{array}$ & 5502,793 & 1 & 5502,793 & 1158,710 & 0,000 \\
$\begin{array}{l}\text { pemecahan } \\
\text { masalah }\end{array}$ & 6258,792 & 1 & 6258,792 & 1317,899 & 0,001 \\
$\begin{array}{l}\text { awal siswa } \\
\text { Model }\end{array}$ & 3105,868 & 2 & 1552,934 & 326,998 & 0,001 \\
$\begin{array}{l}\text { Error } \\
\text { Total }\end{array}$ & 489,154 & 103 & 4,749 & & \\
$\begin{array}{l}\text { Corrected } \\
\text { Total }\end{array}$ & 603948,611 & 107 & & & \\
\hline
\end{tabular}

Berdasarkan ringkasan hasil uji ANAKOVA yang tersaji pada Tabel 8, dapat dideskripsikan sebagai berikut. Pertama, pengaruh keterampilan pemecahan masalah siswa sebelum perlakuan terhadap variabel dependent menunjukan hasil nilai statistik $F^{*}=1317.899$ dengan angka signifikansi 0,001 ( $p<0,05)$. Hal ini menunjukan bahwa kovariat keterampilan pemecahan masalah siswa sebelum perlakuan berpengaruh signifikan terhadap keterampilan pemecahan masalah siswa setelah perlakuan. Pengaruh kovariat ini digunakan sebagai kontrol secara statistik menggunakan ANAKOVA.

Kedua, pengaruh variabel bebas terhadap variabel terikat (kemamuan pemecahan masalah siswa) diperoleh nilai statistik $\mathrm{F}^{*}=326.998$ dengan angka signifikansi 0,001. Angka signifikansi tersebut lebih kecil dari 0,05. Ketiga, nilai $\mathrm{R}$ squared yang diperoleh berdasarkan analisis data adalah 0,943 yang mengindikasikan bahwa model pembelajaran berkontribusi terhadap berbedanya keterampilan pemecahan masalah siswa atar kelompok sebesar 0,943 atau $94.3 \%$. Selanjutnya, analisis signifikansi perbedaan skor rata-rata keterampilan pemecahan masalah siswa melalui LSD. Nilai LSD dapat dihitung dengan mencari nilai rata-rata terestimasi terlebih dahulu dari kedua kelompok.Nilai rata-rata terestimasi dan standar deviasi keterampilan pemecahan masalah siswa masing-masing kelompok disajikan pada Tabel 9. 
Tabel 9. Nilai rata-rata terestimasi dan standar deviasi keterampilan pemecahan masalah siswa antar kelompok

\begin{tabular}{ccccc}
\hline \multirow{2}{*}{ Kelompok } & $\mu$ & \multirow{2}{*}{ SD } & \multicolumn{2}{c}{ Interval Konvidensi 95\% } \\
PBFC & $80,652^{\mathrm{a}}$ & 0,365 & 79,928 & 81,376 \\
TFC & $75,607^{\mathrm{a}}$ & 0,368 & 74,877 & 76,338 \\
DI & $67,507^{\mathrm{a}}$ & 0,365 & 66,783 & 68,231 \\
\hline
\end{tabular}

Signifikansi perbedaan nilai rata-rata keterampilan pemecahan masalah siswa antar kelompok belajar PBFC, TFC, dan DI dianalisis menggunakan LSD. Taraf signifikansi, jumlah sampel kelompok belajar PBFC, TFC, dan DI adalah $\mathrm{n}_{1}=\mathrm{n}_{3}=36, \mathrm{n}_{2}=35$, dengan jumlah model yang digunakan adalah $a=3$. Nilai statistik $t_{\text {tabel }}$ diperoleh sebesar $t_{\text {tabel }}=t_{(0,025,104)}=1,98304$. Rangkuman hasil pengujian signifikansi perbedaan nilai rata-rata keterampilan pemecahan masalah siswa antar kelompok belajar PBFC, TFC, dan DI disajikan pada Tabel 10.

Tabel 10. Signifikansi perbedaan nilai rata-rata keterampilan pemecahan masalah siswa antar kelompok

\begin{tabular}{ccccc}
\hline (I) Kelompok & $(\mathrm{J})$ Kelompok & $\mu(I)-\mu(J)$ & SD & Sig. \\
PBFC & DI & $13,145^{*}$ & 0,519 & 0,001 \\
& TFC & $5,045^{*}$ & 0,518 & 0,001 \\
\multirow{2}{*}{ TFC } & PBFC & $-5,045^{*}$ & 0,518 & 0,001 \\
& DI & $8,100^{*}$ & 0,519 & 0,001 \\
DI & PBFC & $-13,145^{*}$ & 0,519 & 0,001 \\
& TFC & $-8,100^{*}$ & 0,519 & 0,001 \\
\hline
\end{tabular}

Berdasarkan Tabel 10, perbedaan nilai rata-rata keterampilan pemecahan masalah sisswa antar kelompok belajar PBFC dan TFC sebesar 5,045 dengan standar deviasi sebesar 0,518 dan angka signifikansi 0,001. Angka signifikansi lebih kecil dari 0,05 sedangkan $\Delta \mu$ lebih besar dari LSD, LSD yang diperoleh dari hasil perhitungan sebesar 1,5042. Hasil ini menunjukan bahwa keterampilan pemecahan masalah yang dicapai oleh siswa yang belajar dengan model pembelajaran PBFC secara signifikan lebih tinggi dibandingkan siswa yang belajar dengan model pembelajaran TFC.

Perbedaan nilai rata-rata keterampilan pemecahan masalah sisswa antar kelompok belajar TFC dan DI sebesar 8,100 dengan standar deviasi sebesar 0,519 dan angka signifikansi 0,001 . Angka signifikansi lebih kecil dari 0,05 sedangkan $\Delta \mu$ lebih besar dari LSD, LSD yang diperoleh dari hasil perhitungan sebesar 1,5042. Hasil ini menunjukan bahwa keterampilan pemecahan masalah yang dicapai oleh siswa yang belajar dengan model pembelajaran TFC secara signifikan lebih tinggi dibandingkan siswa yang belajar dengan model pembelajaran DI.

Sedangkan, perbedaan nilai rata-rata keterampilan pemecahan masalah sisswa antar kelompok belajar PBFC dan DI sebesar 13,145 dengan standar deviasi sebesar 0,519 dan angka signifikansi 0,001 . Angka signifikansi lebih kecil dari 0,05 sedangkan $\Delta \mu$ lebih besar dari LSD, LSD yang diperoleh dari hasil perhitungan sebesar 1,5042. Hasil ini menunjukan bahwa keterampilan pemecahan masalah yang dicapai oleh siswa yang belajar dengan model pembelajaran PBFC secara signifikan lebih tinggi dibandingkan siswa yang belajar dengan model pembelajaran DI.

Berdasarkan analisis deskriptif dan analisis kovarian satu jalur, secara umum dapat dinyatakan bahwa terdapat perbedaan keterampilan pemecahan masalah siswa antar kelompok model PBFC, TFC, dan DI. Model PBFC lebih baik dibandingkan dengan model TFC ataupun DI 
karena model PBFC mampu mengembangkan keterampilan pemecahan masalah dengan bantuan teknologi, sehingga pembelajaran di dalam kelas menjadi efisien. Selain itu, model PBFC mampu memberikan ruang untuk siswa belajar otentik serta tidak dibatasi ruang dan waktu. Hal tersebut selaras dengan penelitian Hwang et al. (2018) bahwa model pembelajaran PBFC adalah model yang berpusat kepada siswa, sehingga membebaskan siswa belajar dengan gaya belajarnya sendiri sehingga pembelajaran menjadi bermakna. Dasar justifikasi beberapa penelitian yang sesuai dengan temuan penelitian ini dijabarkan sebagai berikut. Penelitian Abu \& Elvin (2019) menunjukan model pembelajaran problem based learning mampu meningkatkan keterampilan pemecahan masalah siswa.

Secara empiris, model pembelajaran PBFC memberikan hasil yang lebih baik terhadap keterampilan pemecahan masalah siswa dibandingkan dengan model TFC maupun model DI. Namun terdapat beberapa hal yang mengakibatkan nilai rata-rata keterampilan pemecahan masalah siswa belum mampu mencapai kategori sangat tinggi (80-100) baik itu dengan model PBFC, TFC, maupun DI. Pertama, singgatnya waktu dalam pemberian perlakuan kepada siswa menggunakan model pembelajaran PBFC dan TFC mengakibatkan siswa belum terbiasa untuk belajar secara bermakna. Kedua, keterampilan pemecahan masalah merupakan kemapuan yang harus diasah dan harus menjadi kebiasaan yang digunakan secara rutin, mengingat keterampilan berpikir tingkat tinggi yang salah satunya adalah keterampilan pemecahan masalah tidak dapat ditingkatkan secara drastis dalam waktu yang singkat. Ketiga, jumlah siswa yang terlalu banyak didalam kelas hingga mencapai 36 orang mengakibatkan pembelajaran menjadi kurang optimal. Keempat, poin utama dalam model pembelajaran ini menggunakan bantuan teknologi dan akses internet, sehingga terdapat beberapa siswa yang memiliki halangan berupa akses internet yang belum memadai sehingga berdampak pada kesulitan dalam belajar di rumah.

Upaya yang dilakukan untuk mengatasi kendala tersebut, yaitu. Pertama, melanjutkan penerapan model pembelajaran PBFC disekolah oleh guru sehingga seiring dengan berjalannya waktu, baik guru maupun siswa terbiasa menggunakan model pembelajaran ini dalam proses pembelajaran sehingga diharapkan pembelajaran menjadi bermakna. Kedua, guru dapat memberi latihan kepada siswa setelah penelitian ini selesai untuk membiasakan siswa dalam mengasah keterampilan pemecahan masalah yang mereka miliki. Ketiga, guru dan peneliti dapat melaksanakan pembelajaran dengan sistem team teaching sehingga pada sesi bimbingan dan latihan individua tau kelompok setiap siswa dapat terfasilitasi. Keempat, siswa diarahkan untuk belajar secara berkelompok untuk mengoptimalkan pembelajaran online agar tidak terdapat siswa yang tertinggal dalam mengakses video dan kuis.

Implikasi dari temuan pada penelitian ini adalah sebagai berikut. Pertama, rata-rata kemampupan pemecahan masalah siswa yang belajar dengan model pembelajaran PBFC berbeda dengan rata-rata keterampilan pemecahan masalah siswa yang belajar menggunakan model pembelajaran TFC maupun DI. Perbedaan rata-rata keterampilan pemecahan masalah antar ketiga kelompok menunjukan rata-rata keterampilan pemecahan masalah siswa pada kelompok model pembelajaran PBFC lebih tinggi dibandingkan kelompok model pembelajaran TFC, dan rata-rata keterampilan pemecahan masalah siswa pada kelompok model pembelajaran TFC lebih tinggi dibandingkan kelompok model pembelajaran DI. Kedua, model pembelajaran TFC relatif lebih unggul dalam meningkatkan keterampilan pemecahan masalah siswa dibandingkan dengan menggunakan model pembelajaran DI, dan akan lebih baik lagi apabila model TFC diintegrasikan dengan model problem based learning yang akan menjadi model pembelajaran PBFC. Ketiga, keterampilan pemecahan masalah siswa pada kelompok model PBFC maupun TFC relatif lebih unggul yang disebabkan oleh sintaks pembelajaran pada kedua model ini mendukung pengoptimalan perkembangan keterampilan pemecahan masalah siswa.

\section{SIMPULAN \& SARAN}


Jurnal Pendidikan Fisika Undiksha, Vol. 10 No.1, Juli 2020

p-ISSN : 2599-2554 (Print), e-ISSN : 2599-2562 (online)

Berdasarkan hasil penelitian dan pembahasan, maka dapat dikemukakan simpulan sebagai berikut.

Terdapat perbedaan keteramplilan pemecahan masalah siswa antara siswa yang belajar menggunakan model pembelajaran Problem Based Flipped Classroom (PBFC), model pembelajaran Traditional Flipped Classroom (TFC), dan model Direct Instruction (DI) dalam pembelajaran kelas XI IPA SMA Negeri 8 Denpasar $\left(F^{*}=326.998\right.$, dengan $\left.p<0,05\right)$. Keterampilan pemecahan masalah siswa pada kelompok yang belajar menggunakan model PBFC relatif lebih tinggi dibandingkan dengan kelomopok siswa yang belajar menggunakan model TFC ataupun model DI.

Saran yang dapat disampaikan yaitu Peningkatan keterampilan pemecahan masalah siswa tidak dapat dilakukan dengan waktu yang singkat sehingga keberlanjutan penggunaan model pembelajaran PBFC di sekolah sangat disarankan guna memperbaiki mutu pendidikan Indonesia Agar proses pembelajaran di kelas yang memiliki jumlah siswa mencangkup 36 siswa atau lebih dapat berjalan optimal, sebaiknya pelaksanaan pembelajaran dilaksanakan dengan sistem team teaching. Pembelajaran online dirumah diarahkan agar siswa belajar dengan kelompok untuk menghindari kendala keterbatasan akses internet bagi siswa yang akan mempelajari video serta menjawab kuis. Untuk penelitian selanjutnya, hendaknya dapat dilaksanakan pada sekolah yang berbeda

\section{UCAPAN TERIMAKASIH}

Peneliti ucapkan terimakasih kepada Dr. Ida Bagus Putu Mardana, M.Si. selaku pembimbing I, Drs. I Nyoman Putu Suwindra, M.Kom. selaku pembimbing II, Dr. Ida Bagus Putu Mardana, M.Si. selaku Ketua Prodi Pendidikan Fisika Universitas Pendidikan Ganesha, Kepala Sekolah, Guru, Staff Pegawai, Siswa-Siswai SMAN 8 Denpasar, serta semua pihak yang telah membantu pembuatan karya ilmiah ini.

\section{DAFTAR PUSTAKA}

Abu, B., \& Elvin, M. (2018). Pengaruh model problem based learning terhadap keterampilan pemecahan masalah pada materi suhu dan kalor di kelas $X$ semester II SMA Negeri 5 Medan T.P. 2017/2018. Jurnal Inovasi Pembelajaran Fisika, 6(4), 1-8. Tersedia pada http://jurnal.unimed.ac.id. Diakses 30 maret 2019

Adhitya, E. N., Prabowo, A., \& Arifudin, R. (2015). Stdudi komparasi model pembelajaran traditional flipped dengan peer instruction terhadap keterampilan pemecahan masalah. Unnes Journal of Mathematics Education. 4(2), 117-126. Tersedia pada https://journal.unnes.ac.id. Diakses 9 Oktober 2019

Bergmann, J., \& Aaron, S. (2012). Flip your classroom: Reach every student in every class every day. (L. Gansel \& T. Wells, Eds.). USA: Courtney Burkholder

Burak, A., Yanpar, Y. T., (2018). The effect of flipped classroom model on students' classroom engagement in teaching english. International Journal of Instruction, 11(2), 385-398. Tersedia pada www.e-iji.net. Diakses 10 Oktober 2019

Candiasa, I M. (2010). Statistik univariat dan bivariat disertai aplikasi SPSS. Singaraja: Unit Penerbitan Universitas Pendidikan Ganesha

Candiasa, I M. (2011). Statistik multivariat disertai aplikasi SPSS. Singaraja: Unit Penerbitan Universitas Pendidikan Ganesha

Chang. Y., Song. A., \& Fang. R. (2018). Integrating ARCS model motivation and PBL in flipped classroom: a case study on a programming language. EURASIA Joural of Mathematics, 
Jurnal Pendidikan Fisika Undiksha, Vol. 10 No.1, Juli 2020

p-ISSN : 2599-2554 (Print), e-ISSN : 2599-2562 (online)

Science and Technology Education, 14(12), 1-15. Tersedia Pada: https://doi.org/10.29333/ejmste/97187. Diakses 31 maret 2019

Chis, A. E., Moldovan, A.-N., Murphy, L., Pathak, P., \& Muntean, C. H. (2018). Investigating flipped classroom and problem-based learning in a programming module for computing conversion course. Educational Technology \& Society, 21(4), 232-247. Tersedia pada (https://creativecommons.org/licenses/by-nc-nd/3.0/). Diakses 31 Maret 2019

Hwang, Gwo-Jen., \& Chen, Pei-Ying. (2019). Effects of a collective problem-solving promotion based flipped classroom on students' learning performances and interactive patterns. Interactive Learning Environments. Tersedia Pada https://www.tandfonline.com/ loi/nile20 . Diakses 30 maret 2019

Jdaitawi, M. (2019). The effect of flipped classroom strategy on students learning outcomes. International Journal of Intruction, 12(3), 665-680. Tersedia pada www.e-iji.net. Diakses 4 Oktober 2019

Nyeneng, P., Suana, W., \& Maulina, H. (2018). Pengembangan perangkat flipped classroom pada mata pelajaran fisika sma. jurnal pendidikan fisika universitas muhammadiyah metro, 6(2), 159-174. Tersedia pada: http://ojs.fkip.ummetro.ac.id/ index.php/fisika/article/view/1193. Diakses 29 Maret 2019.

Organisation for Economic Co-operation and Development (OECD). (2016). programme for international student assessment (pisa). Tersedia pada https://www.oecd.org/pisa/ PISA-2015-Indonesia.pdf. Diakses 30 Maret 2019

Partnership for 21st Century Learning. (2015). P21 Framework Definition. [Online]. Tersedia pada file://E:/Downloads/New\%20folder/Bishop\%20Pre-Con\%202\%20partnership.pdf. Diakses 30 maret 2019

Polya, G. (1973). How to solve it: A new aspect of mathematical method (Second Edition). New Jersey: Princeton University Press

Qader, R. O., \& Arslan, F. Y. (2019). The effect of flipped classroom instruction in writing: a case study with Iraqi EFL learners. Teaching English with Technology, 19(1), 36-55. Tersedia Pada http //www.tewtjournal.org. Diakses 18 Februari 2019

Qiang, J. (2018). Effect of digital flipped classroom teaching method integrated cooperative learning model on learning motivation and outcome. Society for The Teaching of Psychology, 43(1), 2213-2220. Tersedia pada https://pdfs.semanticscholar.org. Diaksees pada 13 Oktober 2019.

Sadia, I W. (2014). Model-model pembelajaran sains kontruktivistik. Yogyakarta: Graha Ilmu

Santyasa, I W. (2017). Pembelajaran Inovatif. Sinngaraja: Undiksha Press.

Santyasa, I W. (2019). Metodologi penelitian. Sinngaraja: Undiksha Press.

Srilaphat, E., \& Jantakoon, T. (2019). Ubiquitous flipped classroom instructional model with learning process of scientific to enhance problem-solving skills for higher education (UFC-PS Model). Canadian Center of Science and Education, 9(1), 76-85. Tersedia Pada https://eric.ed.gov/. Diakses 18 Februari 2019 
Jurnal Pendidikan Fisika Undiksha, Vol. 10 No.1, Juli 2020

p-ISSN : 2599-2554 (Print), e-ISSN : 2599-2562 (online)

Yuliyanto. (2019). Exploring the implementation of weblog-based flipped classroom in teaching civics: Is it feasible and effective? International Journal of Instruction, 12(4), 239-250. Diakses 8 Oktober 2019

Zubaidah, S. (2016). Keterampilan abad ke-21: Keterampilan yang diajarkan melalui pembelajaran. Seminar Nasional Pendidikan. Universitas Negeri Malang. Tersedia pada https://www.researchgate.net/publication/318013627. Diakses 23 Maret 2019 